\title{
"De sidder i deres egen lille gruppe ovre i hjørnet" - en pilotundersøgelse af etniske minoritetsstuderendes møde med studie- og undervisningsmiljøet på farmaceutstudiet
}

\author{
Gro Inge Hansen, videnskabelig assistent, Institut for Læring og Filosofi, Aalborg \\ Universitet.
}

\section{Reviewet artikel}

I artiklen fokuseres $p a ̊$, hvordan studie- og undervisningsmiljøet på farmaceutstudiet på Københavns Universitet (KU) kan risikere at danne ramme for en adskillelse mellem etniske minoritetsstuderendes og etnisk danske studerendes faglige og sociale studieliv. Der argumenteres for, hoordan dette kan påvirke etniske minoritetsstuderendes uddannelsesudbytte og $i$ værste fald bevirke, at de dropper ud af deres studie. Afslutningsvis perspektiveres omkring, hvad man kan gøre for at mindske disse skel i studieog undervisningsmiljøet på farmaceutstudiet. Udgangspunktet for denne artikel er en kvalitativ pilotundersøgelse udført i forbindelse med et speciale om studiepraksis og pædagogisk praksis på medicinstudiet og på farmaceutstudiet på KU (Hansen, 2012).

\section{Indledning og baggrund}

Forskningsfeltet omkring etniske minoritetsstuderende på lange videregående uddannelser er underbelyst, men samtidigt højaktuelt, idet vi lever i et etnisk komplekst samfund, hvor flere og flere etniske minoriteter finder vej til de lange videregående uddannelser (Archer \& Hutchings, 2000; Clegg, 2009; Hoff \& Demirtas, 2009; Mikkelsen, Fenger-Grøndahl, \& Shakoor, 2011). Denne artikel bidrager til at belyse, hvordan mødet mellem etniske minoritetsstuderende og studie- og undervisningsmiljøerne på de lange videregående uddannelser kan rumme problematiske aspekter $^{1}$ samt hvilke bagvedlæggende mekanismer, som kan have indflydelse på dette. Da sådanne problematiske aspekter typisk fremstår implicitte eller usynlige for studerende og undervisere, er de vigtige at sætte fokus på. I mit speciale fandt jeg, at

\footnotetext{
${ }^{1}$ De problematiske aspekter jeg fremhæver i artiklen er ikke nødvendigvis en del af alle etniske minoritetsstuderendes møde med de lange videregående uddannelser. Problematikkerne knytter sig til den specifikke kontekst, som jeg har fået indblik i via pilotundersøgelsen.
} 
etniske minoritetsstuderende i ringere grad indgik i studie-og undervisningsmiljøet på farmaceutstudiet end på medicinstudiet. Årsagerne til dette kan både findes i forskelle på sammensætningen af de to studentergrupper og i forskelle mellem de to studie- og undervisningsmiljøer (Hansen, 2012). I denne artikel fokuserer jeg på mulige årsager i studie- og undervisningsmiljøet på farmaceutstudiet, og artiklen bidrager med forslag til, hvordan man kan forbedre rammerne omkring mødet mellem etniske minoritetsstuderende og det specifikke studie- og undervisningsmiljø.

Man kan afgrænse gruppen af etniske minoritetsstuderende på mange måder. Selvom andengenerationsindvandrere typisk er vokset op i Danmark og har gået mange år i det danske uddannelsessystem, har mange alligevel studieproblemer, som knytter sig til deres etniske og sociale herkomst (Hoff \& Demirtas, 2009; Mikkelsen et al., 2011; Mørck, 1998). Derfor medregner jeg andengenerationsindvandrere, som er født og opvokset i Danmark i min definition af etniske minoriteter. Med inspiration fra anden etnicitetsforskning (Thomsen et al., 2010; Togeby, 2003) fokuserer jeg på skellet mellem den danske majoritet og etniske minoriteter som samlet gruppe. Her er jeg opmærksom på, at der i uddannelsessammenhænge eksisterer undergrupper af både etnisk danske studerende og etniske minoritetsstuderende - bl.a. defineret ud fra køn, hvilket land man stammer fra og familiens socioøkonomiske status.

Tal fra Ministeriet for Flygtninge, Indvandrere og Integration (2004) viser, at dobbelt så mange etniske minoritetsstuderende som etnisk danske studerende dropper ud af deres studie. Ifølge en kvantitativ pilotundersøgelse af Hoff \& Demirtas (2009) giver de etniske minoriteter, som dropper ud, studie- og undervisningsmiljøerne på de danske universitetsuddannelser en del af skylden. Da farmaceutstudiet har en høj andel af etniske minoritetsstuderende (Munk \& Thomsen, 2011), er det værd at vide mere om, hvilke problematikker, der kan være knyttet til mødet mellem etniske minoritetsstuderende og dette specifikke studie- og undervisningsmiljø. Studiemiljøet på farmaceutstudiet opfattes typisk som velfungerende og er en essentiel del af studielivet for mange farmaceutstuderende (Hansen, 2012; Thomsen et al., 2013). Deltagelse i studiesociale aktiviteter opfattes som en del af den legitime studiepraksis (Hansen, 2012). Farmaceutstuderende har dog udtalt, at nogle etniske minoritetsstuderende skiller sig ud ved ikke at tage del i studie- og undervisningsmiljøet på samme måde som deres etnisk danske medstuderende (se for eksempel Begum, 2002). Baggrunden for denne artikel er en undren over, hvorfor disse etniske minoritetsstuderende kan have en anden tilgang til studie- og undervisningsmiljøet end deres etnisk danske medstuderende, og hvilke konsekvenser dette kan have for de berørte etniske minoritetsstuderende.

I min kvalitative undersøgelse af farmaceutstudiet fandt jeg tegn på, at etniske minoritetsstuderende adskilte sig fra deres etnisk danske medstuderende i flere sammenhænge. Dette kom til udtryk ved, at de undersøgte etniske minoritetsstuderende ud- 
trykte, at de oftest ikke deltog i studiesociale aktiviteter med etnisk danske medstuderende. Samtidigt erfarede jeg, at de havde en ringere kontakt til hjælpeundervisere, og at der var markante grupperinger imellem etniske minoritetsstuderende og etnisk danske studerende i faglige sammenhænge, idet laboratoriegrupper og læsegrupper var opdelt mellem de studerende, som tilhørte en etnisk minoritet, og de studerende, som var en del af den etnisk danske majoritet (Hansen, 2012).

For at forklare disse grupperinger vil jeg i denne artikel anlægge en analysevinkel med inspiration fra sociologen Pierre Bourdieu. Samtidig henter jeg inspiration fra den pædagogiske teoretiker Basil Bernsteins skel mellem usynlig og synlig pædagogik. Desuden vil jeg tage afsæt i Cathrines Hasses arbejde med adgang til praksisfællesskaber.

Afslutningsvis vil jeg komme med et bud på, hvad man kan gøre for at modvirke grupperingerne jeg fandt på farmaceutstudiet, hvilket er vigtigt, hvis man vil have en uddannelse, hvor studerendes etniske baggrund ikke er afgørende for deres uddannelsesudbytte.

\section{Kontekst og afgræsning}

Studiemiljøet på farmaceutstudiet italesættes som nævnt generelt af de studerende og underviserne som velfungerende. Studiemiljøet fremhæves også som et yderst positivt træk, når studiet skal præsenteres udadtil (se for eksempel Pharmaschool, 2012; Schmidt, 2012). Deltagelsen i det gode sociale studieliv på farmaceutstudiet kan beskrives som et essentielt træk ved det at være farmaceutstuderende samtidigt med, at deltagelse i sociale aktiviteter på studiet af mange farmaceutstuderende opfattes som et centralt element i deres studiepraksis (dvs. deres måde at være studerende på). Deltagelse i det sociale på studiet er for mange studerende samtidigt en strategi for at undgå at droppe ud af farmaceutuddannelsen (Thomsen et al., 2013). ${ }^{2}$ Deltagelse i studiesociale aktiviteter kan med dette udgangspunkt beskrives som værende en del den legitime og værdsatte studiepraksis på farmaceutstudiet (Hansen, 2012). Via observationer og interviews fandt jeg eksempler på situationer, hvor etniske minoritetsstuderende ikke indgik i faglige og sociale sammenhænge på lige fod med deres etnisk danske medstuderende. Denne artikels omdrejningspunkt er, hvordan dette kan hænge sammen med, at nogle etniske minoritetsstuderendes studiepraksis ikke inkluderer deltagelse i studiesociale sammenhænge og derved ikke er kompatibel med den legitime studiepraksis på farmaceutstudiet.

\footnotetext{
${ }^{2}$ I beskrivelserne af studiemiljøet på farmaceutstudiet skelnes der ikke mellem etnisk danske studerende og etniske minoritetsstuderende.
} 


\section{Empiri og metode}

Empirien, som artiklen bygger på, består af observationer af laboratorieundervisning, en lektiecafe og en erhvervsdag på farmaceutstudiet i efterårssemestret 2011. Endvidere inddrages et fokusgruppeinterview foretaget i forlængelse af observationerne og tre individuelle interviews foretaget $\mathrm{i}$ forbindelse med projektet Widening participation in higher education programmes (RUC, 2009). ${ }^{3}$ Fokusgruppen var heterogent sammensat i forhold til køn og etnicitet og bestod primært af studerende, som også indgik i mine observationer. Med udgangspunkt i Halkiers overvejelser omkring fordele og ulemper ved heterogent sammensatte fokusgrupper (2010) kan den specifikke sammensætning af fokusgruppen have bevirket, at interviewdeltagerne undgik at italesætte de grupperinger mellem etnisk danske studerende og etniske minoritetsstuderende, som jeg observerede flere af fokusgruppedeltagerne indgik i, i undervisningen. Min empiriske undersøgelse skal ligesom Hoff \& Demirtas kvantitative undersøgelse (2009) opfattes som en pilotundersøgelse, hvis fokusområder bør udforskes yderligere. I denne artikel vil jeg supplere mine empiriske fund med et debatoplæg om det at være en etnisk minoritet på farmaceutstudiet (Begum, 2002) samt interviewundersøgelsen At dumpe på FARMA, hvor 14 farmaceutstuderende af blandet etnisk herkomst beskriver deres måde at studere på (studiepraksis) og de dertil knyttede studieproblematikker (Johannsen, 2012).

\section{Usynlig og synlig pædagogisk praksis}

I min analyse af studie- og undervisningsmiljøet henter jeg som nævnt inspiration fra Bernsteins skelnen mellem synlig og usynlig pædagogik (2001). En usynlig pædagogik er en pædagogik, som bygger på implicitte logikker, der ikke bliver italesat. De kan derfor være svære at afkode og imødekomme for studerende, som har en kulturel kapitalsammensætning, som hverken matcher undervisernes kulturelle kapital eller de værdier og praksisser, som er legitime på et studie. Bernstein udpeger etniske minoritetsstuderende samt ugunstigt stillede klasser til at være grupper, der kan have svært ved at afkode en usynlig pædagogik (Bernstein, 2001, s. 114). Uddannelsesforskeren Jens Peter Thomsen (2008) har undersøgt, hvordan synlig og usynlig pædagogisk praksis udfolder sig i den danske universitetsverden. Han finder, at en praksis præget af usynlig pædagogik i en dansk universitetskonktest typisk eksisterer på 'bløde' universitetsuddannelser med et højt karaktergennemsnit som for eksempel litteraturvidenskab. Her er det i høj grad op til de studerende at gennemskue, hvordan de forventes at navigere i studie- og undervisningsmiljøet. På de 'hårde' naturvidenskabelige uddannelser vil der derimod typisk kunne findes en mere synlig pædagogisk praksis. En synlig pædagogisk praksis kan for eksempel udføres ved, at det bliver eksplicit italesat, hvilke begreber man forventer, at de studerende skal

\footnotetext{
${ }^{3}$ Af etiske årsager har jeg anonymiseret alle personer, som medvirker i interviews og observationer ved bl.a. at ændre deres navne.
} 
bruge, og hvordan de skal bruge dem, hvilket vil gøre det nemmere at navigere for etniske minoritetsstuderende (Bernstein, 2001; Harreby, 2011). Hoff \& Demirtas pilotundersøgelse viser, at det største frafald blandt de etniske minoritetsstuderende på de danske universitetsuddannelser kan findes på de humanistisk orienterede uddannelser (38 \%) og det laveste på de sundhedsorienterede uddannelser (5\%). Sammenfaldet mellem en usynlig pædagogisk praksis, som Thomsen finder på 'bløde' humanistiske universitetsuddannelser, og et højt frafald blandt etniske minoritetsstuderende virker iøjnefaldende. Det samme gælder sammenfaldet mellem det lave frafald blandt etniske minoritetsstuderende på de mere 'hårde' sundhedsvidenskabelige uddannelser og Thomsens påpegning af en overordnet synlig pædagogisk praksis på sådanne uddannelser. Disse sammenfald er dog ikke undersøgt til bunds endnu, men peger umiddelbart i retning af, at en mulig konsekvens af en usynlig pædagogisk praksis på danske universitetsuddannelser ikke blot er, at etniske minoritetsstuderende har en dårligere chance for at kunne afkode, hvordan man bør indgå i faglige og sociale sammenhænge, men også har en større risiko for at droppe ud af deres studie.

I mine observationer på farmaceutstudiet fandt jeg, at der på mange måder eksisterer en synlig pædagogisk praksis i overensstemmelse med Thomsens ovenstående antagelser. For eksempel bliver der inddraget mange verbale og visuelle eksempler og anskueliggørelser samtidigt med, at det er entydigt, hvilke perspektiver der er værdsatte og fagligt relevante i undervisningen (Hansen, 2012). Derfor kunne man også tro, at de etniske minoritetsstuderende indgår på lige fod med de etnisk danske studerende i studie- og undervisningsmiljøet på farmaceutstudiet. Min empiri rummer imidlertid eksempler på, at dette ikke er tilfældet, hvilket indikerer et meget komplekst billede af praksis på de danske universitetsuddannelser (se også Thomsen, 2007; 2008; Munk \& Thomsen, 2011; Thomsen et al., 2013,). I denne artikel vil jeg fokusere på de usynlige pædagogiske elementer i den pædagogiske praksis på farmaceutstudiet frem for på de synlige elementer. Dette vil jeg gøre for at fremhæve mulighederne for at forbedre rammerne for mødet mellem etniske minoritetsstuderende og studie-og undervisningsmiljøet på farmaceutstudiet.

At etniske minoritetsstuderende på farmaceutstudiet kan have ringere forudsætninger for at indgå i en usynlig pædagogisk praksis, vil jeg behandle ud fra en Bourdieu-inspireret ramme. ${ }^{4}$ Her vil jeg tage udgangspunkt i sammenhængen mellem kapitalformer og habitus samt Cathrine Hasses analyse af praksisfællesskaber blandt fysikstuderende på KU. Jeg har valgt netop denne teoretiske tilgang, da den ifølge Dohn (2011) og Thomsen (2008) er særligt velegnet til at sætte fokus på, hvordan

\footnotetext{
${ }^{4}$ Refleksioner omkring konsekvenser af at behandle Bernsteins usynlige pædagogik i en Bourdieu-
} inspireret rammeuddybes i mit speciale (Hansen, 2012). 
studerendes forskellige baggrunde kan skabe ulige muligheder for at indgå i studieog undervisningsmiljøer på danske universitetsuddannelser. Dette kan groft sagt resultere $\mathrm{i}$, at det bliver de studerendes måde at være studerende på (studiepraksis) og ikke deres individuelle kognitive evner, som afgør, om de "træder ved siden af" i studie- og undervisningssammenhænge (jf. Dohn 2011, s. 174-176) og i værste tilfælde dropper ud.

\section{Kapitalformer, habitus og praksisfællesskaber}

Jeg fokuserer i analysen af etniske minoritetsstuderendes studiepraksis på kapitalformerne social og kulturel kapital. Bourdieu definerer den sociale kapital som den samlede sum af de faktiske eller potentielle ressourcer, man har adgang til via et holdbart netværk eller medlemskab af en gruppe (Bourdieu, 1986, s. 51). Den sociale kapital kan konverteres til relationer, der for eksempel kan give den nyuddannede et job, en god anbefaling eller et tip om et ledigt job. For de farmaceutstuderende kan det, der deles via den sociale kapital på studiet, defineres som studiesocial kapital, som for eksempel kan bestå af viden om eksamensformer eller om fagligt stof, som det forventes, at man skal kende til på studiet. Den studiesociale kapital er som sagt et centralt element i den legitime studiepraksis på farmaceutstudiet. Den studiesociale kapital kan konverteres til viden om implicitte logikker omkring studiet, som det forventes, man har indblik i. Et indblik som ellers fås via den såkaldt kropsliggjorte kulturelle kapital. Hvis man har en høj mængde kropsliggjort kulturel kapital, har man i undervisningssammenhænge en sans for, hvordan man afkoder og navigerer i undervisningen og for at imødekomme, hvordan underviserne forventer man navigerer - noget studerende med en lav mængde kropsliggjort kulturel kapital ikke nødvendigvis har (Bourdieu \& Passeron, 2006). Derfor vil studerende med en lav mængde kropsliggjort kulturel kapital, som udgangspunkt være ringere stillet i forhold til at skulle navigere i en usynlig pædagogisk praksis end studerende med en høj kulturel kapitalvolumen. Den kropsliggjorte kulturelle kapital hænger i høj grad sammen med den habitus, man tilegner sig igennem livet (Bourdieu, 2000). Habitus er et centralt begreb hos Bourdieu og kan betegnes som et kropsliggjort system af dispositioner, som orienterer aktørernes handlinger, tanker og praksis (Bourdieu, 2004, s. 76-82). I denne artikel er relationen mellem habitat og habituelle dispositioner central. Inden for biologien er et habitat det fysiske område, hvor en organisme naturligt lever. I denne sammenhæng betegner et habitat ikke blot et afgrænset fysisk område, men også et afgrænset socialt område. Derfor kan agenten være placeret i et fysisk habitat (for eksempel et uddannelsessted) uden virkelig at føle sig som en del af det sociale habitat - det vil sige som en del af gruppen eller det sociale miljø. Dette kan være resultatet af et misforhold imellem agentens habituelle dispositioner og de værdier og kapitalformer, som er legitime i habitatet. Hvis dette er tilfældet får agenten en konfliktfuld oplevelse af habitatet i stedet for naturligt for at glide ind i den praksis, som udføres. Det har betydning for, hvorvidt en agent føler, at han/hun pas- 
ser ind og hører til i et habitat (Bourdieu, 1999, s. 123-130). Hvis en agents habitus omvendt er kompatibel med den legitime praksis i habitatet, føler agenten sig placeret i sit rette element eller "som en fisk i vandet". Hvis dette er tilfældet, vil agenten have en praktisk sans for at navigere succesfuldt i den givne praksis og afkode, hvad der er en legitim praksis, og hvad der ikke er (Bourdieu, 2000, s. 147-151, 163). En konsekvens af ovenstående kan være en såkaldt klubeffekt ('Club effect', Bourdieu, 1999, s. 129). En klubeffekt kan opstå, når en minoritetsgruppe som for eksempel etniske minoriteter på farmaceutstudiet ikke oplever, at et habitat er en del af deres naturlige sociale habitat. Dette kan resultere i, at de distancerer sig fra deres omgivelser. Disse distinktioner er med til at forme agenternes praksis og sociale væren og er samtidig basis for eksklusionsprocesser af 'de andre', som ikke medregnes i et 'os' (Bourdieu, 2006, s. 478). For at forklare hvordan klubeffekten kan påvirke uddannelsesudbyttet for de etniske minoritetsstuderende på farmaceutstudiet, vil jeg inddrage Cathrine Hasses undersøgelse af praksisfællesskaber på fysikstudiet på KU. Her finder hun, at de fysikstuderendes køn påvirker deres praksis på studiet og herigennem giver de studerende forskellig adgang til praksisfælleskaber på fysikstudiet (Hasse, 2000, s. 22-46, 305; 2002, s. 56-58). I min fortolkning af praksisfælleskaber har de studerendes habitus, kapitalsammensætning og etniske baggrund betydning for, hvordan de indgår i praksisfælleskaber. ${ }^{5}$ De studerende, som i forvejen naturligt kan indgå i praksisfællesskaberne på farmaceutstudiet, er dem, som i forvejen har uddannelsen som deres naturlige habitat. Socialt forankrede praksisfællesskaber på farmaceutstudiet kan danne ramme for opbygningen af et netværk mellem deltagende studerende, hvor der overføres viden omkring studiepraksis (studiesocial kapital) fra for eksempel ældre studerende til yngre studerende. Det, at praksisfællesskaber med forankring i studiesociale aktiviteter har en central betydning på et socialt orienteret studie som farmaceutstudiet, kan tolkes som værende en del af en usynlig pædagogisk praksis, idet der ikke er eksplicitte regler og vejledninger til, hvordan man indgår i disse. Hvordan dette kan hænge sammen med grupperinger blandt de studerende i både social og faglig kontekst, vil jeg illustrere i følgende afsnit.

\section{Betydningen af det sociale studiefællesskab}

De to farmaceutstuderende Sofija, og Jemil har begge en anden etnisk baggrund end dansk. Uden for studiet har de mange venner, som er etnisk danske. Alligevel deltager ingen af dem i sociale aktiviteter på studiet med deres etnisk danske medstuderende. Den undervisning jeg observerede bar præg af, at etniske minoriteter i laboratoriet hovedsageligt dannede studiegrupper og arbejdsgrupper, som ikke inkludere-

\footnotetext{
${ }^{5}$ Flere undersøgelser viser at køn har stor betydning for etniske minoriteters uddannelsesforløb (se fx Mørck, 1998, 2003; Staunæs, 2004). Derfor kunne det være interessant at undersøge hvordan køn har betydning for etniske minoritetsstuderendes adgang til praksisfællesskaber på lange videregående uddannelser, hvilket dog ikke er omdrejningspunktet for denne artikel.
} 
de etnisk danske studerende. En sådan praksis bevirker, at sociale grupperinger, som opstår i studiemiljøet på farmaceutstudiet, også kommer til udtryk i grupperinger omkring faglige fælleskaber. På den måde er der en risiko for, at etniske minoritetsstuderende indirekte afskæres fra adgang til praksisfællesskaber med den etnisk danske majoritet på studiet. Et eksempel på, hvordan en etnisk dansk farmaceutstuderende opfatter de omtalte grupperinger, er denne udtalelse fra det individuelle interview med Benjamin:

"Jeg snakker sjovt nok med dem, der kommer meget til fredagsbar, og det har jo så for eksempel gjort, at jeg overhovedet ikke snakker med indvandrerne derinde. Og jeg kan ikke huske deres navne. De er ikke til noget, og man ser dem sådan lige hurtigt, når man er til forsøg sammen. Jeg kan godt kende deres ansigter og se, at de går på mit hold, men de kommer ikke til nogle sociale arrangementer, og så lærer jeg dem ikke at kende. Drengenes navne kan jeg, men det er fordi, jeg snakkede med dem til studiestart. Pigernes navne...det er sådan...de gør heller ikke noget for at snakke med os. De sidder i deres egen lille gruppe ovre i hjørnet."

Benjamins udlægning af disse grupperinger peger på, at han ikke har et forhold til de etniske minoritetsstuderende. Han kender ikke pigernes navne, da de ikke er med i fredagsbaren og bare er nogle, man "ser...lige hurtigt" til forsøgene i laboratorieundervisningen. Benjamins udsagn illustrerer, hvordan etniske minoritetsstuderende på farmaceutstudiet kan opfattes af deres medstuderende, som nogle der "ikke er til noget", idet de ikke indgår i faglige og sociale fællesskaber med de etnisk danske studerende. Mønstret går igen i Johannsens interviewundersøgelse (2012, s. 74-75), hvor især piger med tørklæde fremhæves som en gruppe, der af deres medstuderende opfattes som nogle, der holder sig for sig selv og ikke deltager i studiesociale aktiviteter på farmaceutstudiet. Dette indikerer en os/dem skelnen mellem de etnisk danske og de etniske minoriteter på farmaceutstudiet. I et debatoplæg i farmaceutstudiets tidligere studieblad udtaler en kvindelig farmaceutstuderende med etnisk minoritetsbaggrund sig om sociale skel mellem etniske danskere og etniske minoriteter på studiet. Hun forklarer, at etniske minoriteter sidder sammen i kantinen og holder pause, fordi de har et fælles kulturelt værdigrundlag og derfor kan slappe mere af, når de er sammen (Begum, 2002, s. 9). Hun mener, at grunden til, at etniske minoritetsstuderende foretrækker at være sammen med andre etniske minoritetsstuderende, er, at "man er mere tryg ved de rammer, man er vant til", og at det er et "pusterum", hvor man ikke er i mindretal (Begum, 2002, s. 9). Denne udlægning kan tyde på, at nogle etniske minoritetsstuderende ikke oplever farmaceutstudiet som et socialt habitat, hvor de kan agere naturligt og føle sig hjemme. Debatoplæggets forfatter beskriver sig selv som en del af en minoritet og udtrykker tendens til en klubeffekt blandt de etniske minoriteter på farmaceutstudiet. Klubeffekten kan altså være en forklaring på, hvorfor nogle etniske minoritetsstuderende danner interne grupper 
i studie- og undervisningsmiljøet på farmaceutstudiet, hvor de i højere grad kan føle sig tilpasse og slappe af. De indgår ikke i lige så høj grad i den sociale studiepraksis som de etnisk danske studerende, da de ikke føler, de hører til og det ikke er et naturligt element i deres studieliv. Som sagt kan deltagelse i disse vigtige sociale praksisfællesskaber på farmaceutstudiet siges at være en del af en usynlig pædagogisk praksis, som disse etniske minoritetsstuderende derfor muligvis ikke kan efterleve. Dette kan skabe en ond cirkel for de berørte etniske minoritetsstuderende, da deltagelse i praksisfællesskaberne kunne give dem mulighed for at lære at navigere i den usynlige pædagogiske praksis, de som udgangspunkt ikke har adgang til via deres kropsliggjorde kulturelle kapital og habituelle dispositioner. I en dansk uddannelseskontekst finder Thomsen et al. (2010, s. 29-35), at etniske minoritetsstuderende har en mere målorienteret og instrumentel tilgang til deres studie og derfor ikke ser det at være studerende som et mål i sig selv men i stedet som et skridt på vejen mod en prestigefuld og brugbar karriere. I Johannsens interviewundersøgelse med farmaceutstuderende er det netop etniske minoritetsstuderende, som har denne indstilling til studiet (2012, s. 13-16). En sådan mere instrumentel og målorienteret studietilgang kan være en del af forklaringen på, hvorfor etniske minoritetsstuderende på farmaceutstudiet har en studiepraksis, hvor deltagelse i studiesociale aktiviteter ikke vægtes højt. En anden årsag kan være, at alkohol er en stor del af mange studiesociale aktiviteter på farmaceutstudiet. For eksempel nævner den kvindelige farmaceutstuderende med anden etnisk herkomst i debatoplægget, at dette er en del af grunden til, at hun ikke deltager i studiesociale sammenhænge (Begum, 2002).

\section{Den svære relation til underviserne}

En konsekvens af klubeffekten kan være, at de berørte etniske minoritetsstuderende udvikler en dårligere relation til underviserne, hvilket i endnu højere grad afskærer dem fra deltagelse i vigtige praksisfælleskaber. Den canadiske uddannelsessociolog Stanton-Salazar (2004) udpeger etniske minoriteter som en gruppe, der kan have svært ved at skabe relationer til betydningsfulde agenter i uddannelsessystemet såsom undervisere og vejledere. Dette fandt jeg også eksempler på i mine observationer i laboratorieundervisningen. Her var en ældre studerende tilknyttet som hjælpeunderviser. Ved afslutningen på en undervisningsdag sad hjælpeunderviseren og snakkede med en gruppe etnisk danske studerende om studierelaterede, ikke-faglige emner. Han trak på sine egne erfaringer som studerende og gav gode råd om, hvordan de kunne gribe et udvekslingsophold an. Dette er et eksempel på, hvordan studiekapital kan blive videregivet i praksisfællesskaber. Johannsen finder på samme vis, at de etniske minoritetsstuderende fra interviewundersøgelsen har sværere ved at afkode og efterleve implicitte praksisser på farmaceutstudiet. For eksempel forbereder flere etnisk danske farmaceutstuderende sig til eksamen ved at løse eksamens- 
opgaver fra tidligere år i stedet for at læse op på pensum og komme til forelæsningerne, hvilket ikke i samme grad er tilfældet for de interviewede etniske minoritetsstuderende (Johannsen, 2012, s. 44-49, 74-76).

I fokusgruppen pointerer to etniske minoritetsstuderende, at de opfatter en god underviser på farmaceutstudiet som én, de studerende kan have en personlig relation til, og som én, der kan hjælpe dem til at navigere i det faglige. De har altså begge afkodet den usynlige pædagogiske praksis, som bygger på, at en personlig relation til underviserne kan give adgang til studiekapital, som kan hjælpe dem med at klare sig bedre på uddannelsen. De forstår vigtigheden af at have adgang til fagligt relaterede praksisfællesskaber omkring studiet, men med udgangspunkt i mine observationer og i udtalelserne fra de individuelle interviews kan man stille spørgsmål ved, om alle etniske minoritetsstuderende på farmaceutstudiet formår at skabe de afgørende relationer til underviserne og tage del i de vigtige praksisfællesskaber på samme vis som deres etnisk danske medstuderende.

Efter mit speciale bad jeg om feedback på specialet fra de involverede parter. Her påpegede en underviser, at han synes, at især de kvindelige etniske minoritetsstuderende indtog en mere underdanig 'elevagtig' attitude i undervisningen end de andre studerende. Man kan sige, at han opfattede dem som en gruppe, som skilte sig negativt ud ved ikke at navigere på den rigtige måde i undervisningssammenhænge. Dette understreger, at andre faktorer som for eksempel køn, socioøkonomisk status og den specifikke kontekst på studiet også er betydningsfulde, når man undersøger etniske minoriteters studiepraksis (Göransson \& Lidegran, 2005; Mørck, 1998; Archer \& Hutchings, 2000).

\section{Perspektivering}

Jeg har med denne artikel forsøgt at sætte fokus på, hvordan mødet mellem studieog undervisningsmiljøet på farmaceutstudiet og nogle etniske minoritetsstuderende kan rumme problematiske aspekter. Undersøgelsen illustrerer, at nogle af de etniske minoritetsstuderende på farmaceutstudiet kan lide under klubeffekter. Sådanne effekter giver en ringere adgang til praksisfælleskaber og en studiesocial kapital, som kan hjælpe de ramte etniske minoritetsstuderende med at navigere i den usynlige pædagogiske praksis. Dette kan betyde, at disse etniske minoritetsstuderende får et ringere uddannelsesudbytte end deres medstuderende. Muligvis kan den yderste konsekvens af dette være, at de ender med at droppe ud. Hvordan dette udfolder sig på de specifikke universitetsstudier er ikke undersøgt til bunds endnu, men med denne pilotundersøgelse som udgangspunkt kunne det være interessant at undersøge nærmere. Om den ringere deltagelse i studiesociale sammenhænge også kan påvirke de etniske minoritetsstuderende på farmaceutstudiets fremtidige arbejdsliv er heller ikke undersøgt endnu, hvilket kunne være en anden tråd man kunne tage op i fremtidig forskning. 
Min pilotundersøgelse peger på, at man på farmaceutstudiet bør arbejde mere målrettet med den sociale dimension af læringsmiljøet, hvilket også pointeres i Johannsens interviewundersøgelse (2012). Derfor vil jeg afsluttende komme med overvejelser omkring, hvordan dette kan gøres i praksis. Hvis man vender blikket imod medicinstudiet, er der ikke i samme grad grupperinger mellem de etnisk danske og etniske minoriteter hverken i studiemiljøet eller i faglige sammenhænge. Dette kan som sagt skyldes flere ting - for eksempel at det er en anden gruppe af etniske minoritetsstuderende, som læser medicin (Hansen, 2012; Munk \& Thomsen, 2011). Jeg vil dog fremhæve, at det sociale miljø på medicinstudiet i vidt omfang er bygget op omkring ekstra-curriculære aktiviteter som for eksempel deltagelse i en kirurgklub eller i Læger uden Grænser som en mulig del af forklaringen (Hansen, 2012). Deltagelse i ekstra-curriculære aktiviteter kan være en strategi til at knække de koder, som ellers kan fremstå usynlige for studerende med en lav mængde kropsliggjort kulturel kapital (Thomsen et al., 2013). Fagligt funderede ekstra-curriculære aktiviteter kan muligvis i højere grad appellere til den instrumentale og målorienterede studiepraksis, som kan findes blandt etniske minoritetsstuderende (Hansen, 2012). Derfor kunne det være relevant at kigge imod medicinstudiets fagligt funderede studiemiljø og fokusere på at synliggøre for eksempel Farmaceuter uden Grænser eller andre fagligt funderede foreninger, da deltagelse i disse kunne hjælpe etniske minoritetsstuderende med en lav mængde kropsliggjort kulturel kapital til at få adgang til praksisfælleskaber, hvor de kan lære at indgå i den usynlige pædagogiske praksis på farmaceutstudiet. En anden mulighed er, at man på farmaceutstudiet strukturelt prøvede at styrke etniske minoritetsstuderendes adgang til praksisfælleskaber, som inkluderer den etnisk danske majoritet på studiet og underviserne. For eksempel kunne man sikre, at en underviserstyret gruppedannelsesproces i laboratorieundervisningen altid finder sted, oprette 1-1 mentorordninger for studerende omkring studiestart eller uddele kontaktlærerfunktioner til underviserne. Sådanne tiltag vil kunne medvirke til, at det ikke er etniske minoritetsstuderendes studiepraksis men deres faglige evner, som er afgørende for, om de sorteres fra på farmaceutstudiet.

Gro Inge Hansen er kandidat i Pædagogisk Sociologi fra Institut for Pædagogik og Uddannelse, Aarhus Universitet og har en bachelor i Sociologi fra Sociologisk Institut, Købehavns Universitet. I sit speciale undersøger hun ud fra en feltanalytisk tilgang pædagogisk praksis og studiepraksis med fokus på etnicitet på medicinstudiet og farmaceutstudiet på Københavns Universitet.

\section{Litteratur}

Archer, L. \& Hutchings, M. (2000). 'Bettering Yourself'? Discourses of risk, cost and benefit in ethnically diverse, young working-class non-participants' constructions of higher education. British Journal of Sociology of Education, 21(4), 19. 
Begum, F. D. (2002). Isolation, assimilation eller integration på DFH? PLEXUS, 34(3). Retrieved from Den Farmaceutiske Højskoles website:

http://www.farma.ku.dk/fileadmin/Publikationer/Plexus/2002/2002_plexus_ma j.pdf

Bernstein, B. (2001). Klasseforskelle og pædagogisk praksis. In L. Chouliaraki \& M. Bayer (Eds.), Basil Bernstein, Pædagogik, diskurs og magt (s. 94-133). København: Akademisk Forlag.

Bourdieu, P. (1986). The forms of capital. I: J. G. Richardson (Ed.), Handbook of theory and researchfor the sociology of education. New York: Greenwood Press.

Bourdieu, P. (1999). Site effects. In: P. Bourdieu, A. Accardo, G. Balazs, S. Beaud, F. Bonvin, E. Bourdieu, P. Bourgois, S. Broccolichi, P. Champagne, Rosine Christin, J.-P. Faguer, S. Carcia, R. Lenoir, F. Euvrard, M. Pialoux, L. Pinto, D. Podalydès, A. Sayad, C. Soulié \& L. J. D. Wacquant (Eds.): The Weight of the world. Social suffering in comtemorary society (s. 123-168). Stanford, California: Standford University Press.

Bourdieu, P. (2000). Bodily knowlegde. In: P. Bourdieu, Pascalian meditations (s. 128163). Cambridge, Oxford: Polity Press.

Bourdieu, P. (2004). Af praktiske grunde. København: Hans Rietzels Forlag.

Bourdieu, P. (2006). Distinction, a social critique of the judgement of taste. New York, London: Routledge, Taylor \& Francis Group.

Bourdieu, P. \& Passeron, J.-C. (2006). Reproduktionen. Bidrag til en teori om undervisningssystemet. København: Hans Reitzels Forlag.

Clegg, S. (2009). Forms of knowing and academic development practice. Studies in Higher Education, 34(4), 403-416.

Dohn, N. B. (2011). Bag om dikotomierne - problematisering af implicitte forudsætninger. In: J. E. Feldt \& N. B. Dohn (red.), Universitetsundervisning i det 21. århundrede. Læring, dannelse, marked (s. 156-186). Odense: Syddansk Universitetsforlag.

Göransson, A. \& Lidegran, I. (2005). En gränslös akademi? Vägar till den akademiska toppen med utländsk bakgrund i bagaget. In: Makten och mångfalden, Eliter och etnicitet $i$ Sverige. Uppsala: Regeringskansliet, justitsdepartementet.

Halkier, B. (2010). Fokusgrupper. In: S. Brinkmann \& L. Tanggaard (red.), Kvalitative metoder, en grundbog (s. 121-136). København: Hans Reitzels Forlag.

Hansen, G. (2012). "Jo større, jo bedre?", en feltanalytisk undersøgelse af praksis på medicin-og farmaceutstudiet med fokus på etnicitet $i$ en fusionstid (kandidatspeciale), Aarhus Universitet, København.

Harreby, S. (2011). Naturfag gavner integration. Danske bioanalytikere, 04.

Hasse, C. (2000). Kraftfeltet - kulturelle lereprocesser i det fysiske rum. (ph.d.afhandling), Københavns Universitet, København.

Hasse, C. (2002). Kultur i bevægelse: Fra deltagerobservation til kulturanalyse - i det fysiske rum. Frederiksberg: Samfundslitteratur. 
Hoff, J. \& Demirtas, M. (2009). Frafald blandt etniske minoritetsstuderende på universitetsuddannelserne i Danmark. København: Københavns Universitet, Institut for Statskundskab.

Johannsen, B. F. (2012). At dumpe på FARMA. En interviewundersøgelse. IND skriftserie (Vol. 25): Institut for Naturfagenes Didaktik.

Mikkelsen, F. Fenger-Grøndahl, M. \& Shakoor, T. (2011). I Danmark er jeg født..., Etniske minoritetsunge i bevægelse. København: Center for Ungdomsforskning, Trygfonden, Frydenlund.

Ministeriet for Flygtninge, Indvandrere og Integration (2004). Årbog om udlændige $i$ Danmark 2004 - status og udvikling. København: Ministeriet for Flygtninge, Indvandrere, Flygtninge og Integration.

Munk, M. D. \& Thomsen, J. P. (2011). Widened participation and unequal access to higher educationin Denmark. Paper presented at the 10th conference of the European Sociological Association, Geneve.

Mørck, Y. (1998). Bindestregsdanskere - fortællinger om køn, generationer og etnicitet. Frederiksberg: Forlaget Sociologi, c/o Samfundslitteratur.

Mørck, Y. (2003). Narratives of the intersections of masculinities and ethnicities in a Danish high school class. NORA. Nordic Journal of Women's Studies, 2(11).

Pharmaschool (2012, 4.10.2012). Studerende på Pharmaschool. Retrieved 1.3, 2013 from http://www.farma.ku.dk/index.php?id=545

RUC. (2009). Widening participation in higher education programmes - identifying barriers and opportunities for students from lower educational backgrunds.

Retrieved 1.3, 2013 from http://rucforsk.ruc.dk/site/da/projects/wideningparticipation-in-higher-education-programmes--identifying-barriers-andopportunities-for-students-from-lower-educational-backgrunds(ba7daab025e6-457c-bf93-bac9e15c7bbd).html

Schmidt, B. (2012). Det farmaceutiske fakultet får ny struktur og nyt navn. Farmaci, (1), 34 - 36. Retrieved from http://infolink2003.elbo.dk/apotekerforeningen/Forsider/Farmaci012012.pdf Stanton-Salazar, R. (2004). Social capital among working-class minority students. In M. A. Gibson, P. Gàndara \& J. P. Koyama (Eds.), School Connections: U.S. Mexican youth, peers, and school achievement (s. 18-38). New York and London: Teachers College Press.

Staunæs, D. (2004). Køn, etnicitet og skoleliv. Frederiksberg: Samfundslitteratur.

Thomsen, J. P. (2007). Senmodernitetens universitetsstuderende? Dansk Universitetspædagogisk Tidsskrift, (4), 4-11.

Thomsen, J. P. (2008). Social differentiering og kulturel praksis på danske universitetsuddannelser (ph.d.-afhandling). Roskilde: Forskerskolen i Livslang Læring, Roskilde Universitetscenter. 
Thomsen, J. P. Moldenhawer, B. \& Kallehave, T. (2010). Ethnic differences in education in Denmark. In Survey report EDUMIGROM: Ethnic Differences in Education and Diverging Prospects for Urban Youth in an Enlarged Europe. Center For Policy Studies: Central European University.

Thomsen, J. P. Munk, M. Eiberg-Madsen, M. \& Hansen, G. I. (2013). Educational strategies among Danish university students from professional and workingclass backgrounds. Comparative Education Review, 57(3). Retrieved from http://vbn.aau.dk/da/publications/the-educational-strategies-of-danishuniversity-students-from-professional-and-workingclassbackgrounds(f851bfa1-5962-426e-861d-9412cab01095).html

Togeby, L. (2003). Fra fremmedarbejdere til etniske minoriteter. Århus: Aarhus Universitetsforlag. 